\title{
Persepsi Penyakit Pasien Dengan Ulkus Kaki Diabetik \\ Di Banjarmasin, Kalimantan Selatan, Indonesia
}

\author{
${ }^{1}$ Cynthia Eka Fayuning Tjomiadi \\ ${ }^{1}$ Program Studi Sarjana Keperawatan Universitas Sari Mulia Banjarmasin \\ *correspondence author: Telepon: 0511-3268105, Fax: 0511-3270134, E-mail: \\ tjomiadicynthia@gmail.com
}

DOI: https://doi.org/10.33859/dksm.v10i1.433

Abstrak
Latar Belakang: Tingginya kejadian ulkus kaki diabetik di dunia terutama di Indonesia membawa
pertanyaan besar, apa faktor yang menyebabkan fenomena tersebut. Hasil penelitian terbaru
menunjukan adanya peranan persepsi terhadap penyakit dapat memoengaruhi signifikansi kejadian
ulkus kaki diabetik.
Tujuan: Penelitian ini bertujuan untuk mendeskripsikan bagaimana persepsi penyakit terhadap ulkuk
kaki diabetik di Banjarmasin, Kalimantan Selatan, Indonesia.
Metode: Studi deskriptif dengan metode cross-sectional dilakukan di poliklinik kaki diabetik Rumah
Sakit Umum Daerah Ulin Banjarmasin. Persepsi penyakit diukur dengan menggunakan Brief Illness
Perceptions Questionnaire (BIPQ).
Hasil: Domain dari perspsi penyakit telah berhasil dideskripsikan. Ulkus kaki diabetik dianggap
sebagai penyakit kronis yang akan memberikan dampak besar terhadap kehidupan sehari-hari dan
sulit di identifikasi. Kurangnya pemahaman tentang ulkus kaki diabetik juga ditemukan dari hasil
penelitian ini


Dinamika Kesehatan Jurnal Kebidanan dan Keperawatan Vol 10 No. 1 Juli 2019 (ISSN: 2086-3454 EISSN: 2549-4058)

url: http://ojs.dinamikakesehatan.unism.ac.id DOI : https://doi.org/10.33859/dksm.v10i1

Persepsi Penyakit Pasien Dengan Ulkus Kaki Diabetik

Di Banjarmasin, Kalimantan Selatan, Indonesia

\title{
Perception of Patient's Disease with Diabetic Foot Ulcers
}

In Banjarmasin, South Kalimantan, Indonesia

\begin{abstract}
Background The urgency of the high incidence of Diabetic Foot Ulcer (DFU) around the world especially in Indonesia bring a big question, what are the factor that causes this phenomenon. Evidence from the recent research showed the role of illness perception and its significance on DFU. Objective This study aims to describe what are the illness perceptions of patients with DFU in Banjarmasin, South Borneo, Indonesia.

Methods A descriptive cross-sectional study design was used. The DFU patients who required routine follow up in podiatry outpatient department of Ulin General Hospital in Banjarmasin were recruited. The illness perceptions were measured by using Brief Illness Perceptions Questionnaire (BIPQ).

Results The mean of the illness perceptions domain has been described. DFU considered as chronic disease which bring a major impact on daily life, difficult to identify. The lack of understanding on DFU also has been endorsed by the participants in this study.
\end{abstract}

Keywords: Diabetic Foot Ulcer, Perception of Disease 
Dinamika Kesehatan Jurnal Kebidanan dan Keperawatan Vol 10 No. 1 Juli 2019 (ISSN: 2086-3454 EISSN: 2549-4058) url: http://ojs.dinamikakesehatan.unism.ac.id DOI : https://doi.org/10.33859/dksm.v10i1

Persepsi Penyakit Pasien Dengan Ulkus Kaki Diabetik

Di Banjarmasin, Kalimantan Selatan, Indonesia

Ulkus kaki diabetik adalah salah satu

komplikasi mikrovaskular yang rata-rata

terjadi sebanyak $15 \%$ pada pasien diabetes

selama hidup mereka (The Canadian

Association of Wound Care, 2016). Sekali

seseorang terkena ulkus kaki diabetik, mereka

akan rentan untuk terkena komplikasi lanjutan

seperti amputasu dan infeksi, hingga harus

dilakukan rawat inap (International Diabetes

Federation [IDF], 2015). Lebih jauh lagi, pasien ulkus kaki diabetik menghabiskan 20\%$40 \%$ sumber dana kesehatan untuk diabetes (Lepäntalo dkk, 2011). Secara singkat, ulkus kaki diabetik merupakan sebuah permasalahan besar di dunia, dengan kejadian di Indonesia sendiri yang cukup tinggi mencapai 7\%-24\% (Yusuf dkk, 2016).

Dampak ulkus kaki diabetik sendiri akan memperburuk kondisi pasien diabetes. Lamanya penyembuhan yang memerlukan waktu beberapa minggu hingga berbulan bulan dapat menyebabkan pasien menghadapi berbagai masalah tidak hanya secara fisik, namun juga emosional, sosial ekonomi dan spiritual (Gilpin dan Lagan, 2008).
Ada banyak

faktor

yang

mempengaruhi kejadian ulkus diabetik seperti faktor demografi, luka ulkus dan amputasi sebelumnya, hingga faktor spiritual (Yusuf dkk, 2016). Namun, jika kita memperluas analisa terhadap faktor psikologis, teradapat satu faktor yang jarang diidentifikasi dalam penelitian keperawatan.

Pengaruh model self-regulatory terhadap penyakit mungkin adalah jawabannya. Menurut Common Sense SelfRegulatory Model (CSM) milik Leventhal menyatakan ada 8 domain inti yang terdiri dari identity (kepercayaan terkait label atau menamai suatu tanda gejala suatu penyakit), consequences (kepercayaan tentang dampak penyakit secara holistik), timeline (durasi penyakit, apakah akut ataupun kronis), personal control (kepercayaan dalam kemampuan dalam mengontrol penyakitnya), treatment control (kepercayaan terhadap keefektifitasan pengobatan), coherence (pemahaman terhadap penyakit yang diderita), emotional representations (dampak emosional penyakit) dan causal representations 
Dinamika Kesehatan Jurnal Kebidanan dan Keperawatan Vol 10 No. 1 Juli 2019 (ISSN: 2086-3454 EISSN: 2549-4058) url: http://ojs.dinamikakesehatan.unism.ac.id DOI : https://doi.org/10.33859/dksm.v10i1

Persepsi Penyakit Pasien Dengan Ulkus Kaki Diabetik

Di Banjarmasin, Kalimantan Selatan, Indonesia

(kepercayaan terhadap penyebab penyakit)

(Leventhal dan Burns, 2016).

Konsep persepsi pernyakit sendiri merujuk pada kepercayaan pasien terhadap penyakit mereka berdasarkan pengalaman personal terkait tanda dan gejala, pengetahuan sebelumnya, budaya dan faktor sosial. Secara umum, persepsi penyakit yang negatif akan berhubungan dengan perilaku dan manajemen penyakit yang negatif (Katavić, Tanacković dan Badurina, 2016), dampaknya pasien dengan persepsi penyakti negatif dapat menolak untuk mengikuti regimen pengobatan dan sulit menerapkan kebiasaan hidup sehat.

\section{Persepsi penyakit masing masing} individu itu unik dan berbeda. Perawat perlu memahami bagaimana menyampaikan pelayanan keperawatan secara tepat guna menghindari miskomunikasi. Alih-alih memberi label pasien sebagai individual yang “tidak patuh", perawat perlu mengidentifikasi faktor yang mempengaruhi persepsi pasien terhadap penyakit dan menganalisa hal-hal yang dapat disesuaikan ataupun dimodifikasi (McDonald, 2011).

Bukti dari penelitian terbaru menemukan domain identity, personal control dan illness coherence mempengaruhi cara pasien melakukan kebiasaan perawatan diri dan secara signifikan mempengaruhi output pasien ulkus diabetik (Vedhara dkk, 2014). Lebih jauh lagi, persepsi penyakit pasien dengan ulkus kaki diabetik secara signifikan mempengaruhi cara pasien melakukan upaya pencegahan dan perawatan kaki diabetik (Walburn dkk, 2017).

Hingga saat ini, belum adanya penelitian terkait persepsi penyakit dengan ulkus kaki diabetik di Indonesia. Maka penelitian ini bertujuan untuk mengidentifikasi persepsi penyakit pasien dengan ulkus kaki diabetik di Banjarmasin, Kalimantan Selatan, Indonesia.

\section{Metode}


Dinamika Kesehatan Jurnal Kebidanan dan Keperawatan Vol 10 No. 1 Juli 2019 (ISSN: 2086-3454 EISSN: 2549-4058)

Penelitian ini merupakan penelitian

deskriptif dengan pendekatan cross-sectional.

Sample penelitian ini adalah pasien poliklinik

kaki diabetik Rumah Sakit Umum Daerah

(RSUD) Ulin Banjarmasin, Kalimantan

Selatan, Indonesia. Penelitian ini telah disetujui oleh komite etik RSUD Ulin. Jumlah sample dihitung dengan formula finite population mean (Wayne, 1995). Standar deviasi 2.9 berdasarkan penelitian sejenis sebelumnya (Vedhara dkk, 2016) dengan alpha value $(\propto) 0.05$ dan error value (d) 0.05 .

$$
\begin{gathered}
\eta=\frac{\mathrm{N} \sigma^{2} z_{1-\frac{\alpha}{2}}^{2}}{d^{2}(N-1)+\sigma^{2} z_{1-\frac{\alpha}{2}}^{2}} \\
\eta=\frac{140.2 .9^{2} \cdot 0.29^{2}}{0.05(140-1)+2.9^{2} \cdot 0.29^{2}}=103
\end{gathered}
$$

ditambahkan untuk antisipasi menghindari kurangnya partisipan. Jumlah akhir sample adalah 134 .

Instrumen dalam penelitian ini dibagi menjadi tiga bagian yang terdiri dari data demografi, riwayat penyakit dan terjemahan bahasa Indonesia Brief Illness Perceptions Questionnaire (BIPQ). BPIQ telah dipakai dalam penelitian berbagai jenis penyakit dan sangat disarakankan digunakan pada situasi rawat jalan/ poliklinik (Broadbent dkk, 2006). Partisipan dalam penelitian diberikan informed consent setelah mendapatkan penjelasan terkait tujuan, keuntungan dan hak untuk berhenti dalam mengikuti proses penelitian.

\section{Hasil}

Karakteristik demografi partisipan dipresentasikan pada tabel 1. Sebagian besar partisipan laki-laki dengan rata-rata usia 54 tahun. Mayoritas partisipan adalah etnik Banjarmasin dan beragama Islam. Latar belakang pendidikan partisipan penelitian, sebesar $6.7 \%$ tidak pernah menjalani pendidikan formal. Lebih lanjut lagi, sebagian besar partisipan memiliki riwayat keluarga dengan ulkus kaki diabetik. 
Dinamika Kesehatan Jurnal Kebidanan dan Keperawatan Vol 10 No. 1 Juli 2019 (ISSN: 2086-3454 EISSN: 2549-4058) url: http://ojs.dinamikakesehatan.unism.ac.id DOI : https://doi.org/10.33859/dksm.v10i1

Persepsi Penyakit Pasien Dengan Ulkus Kaki Diabetik

Di Banjarmasin, Kalimantan Selatan, Indonesia

Tabel 1. Karakteristik demografi pasien dengan ulkus kaki diabetik di Banjarmasin, Kalimantan Selatan, Indonesia $(\mathrm{N}=134)$

\begin{tabular}{|c|c|c|}
\hline Variable & N (134) & $\%$ \\
\hline \multicolumn{3}{|l|}{ Gender } \\
\hline Laki-laki & 72 & 53.7 \\
\hline Perempuan & 62 & 46.3 \\
\hline \multicolumn{3}{|l|}{ Usia } \\
\hline $35-47$ & 34 & 25.4 \\
\hline $48-59$ & 55 & 41 \\
\hline $60-75$ & 45 & 33.5 \\
\hline Mean usia (SD) & $54.37 \pm 9.1$ & \\
\hline \multicolumn{3}{|l|}{ Agama } \\
\hline Islam & 132 & 98.5 \\
\hline Kristen & 2 & 1.5 \\
\hline \multicolumn{3}{|l|}{ Etnik } \\
\hline Banjarmasin & 105 & 78.4 \\
\hline Jawa & 18 & 13.4 \\
\hline Dayak & 5 & 3.7 \\
\hline Others & 6 & 4.5 \\
\hline \multicolumn{3}{|l|}{ Latar Belakang Pendidikan } \\
\hline Tidak ada & 9 & 6.7 \\
\hline Sekolah Dasar & 52 & 38.8 \\
\hline Sekolah Menengah Pertama & 24 & 17.9 \\
\hline Sekolah Menengan Atas & 26 & 19.4 \\
\hline Universitas & 23 & 17.2 \\
\hline
\end{tabular}

Riwayat penyakit partisipan dipresentasikan pada tabel 2. Sebagian besar partisipan menderita ulkus kaki diabetik kurang dari 5 tahun. Lebih lanjut lagi, sebagian besar paritispan memiliki penyakit penyerta dan belum pernah memiliki ulkus kaki diabetik sebelumnya. Sebagian besar partisipan menggunakn insulin. Lebih dari setengah partisipan tidak melakukan perawatan kaki rutin dan tidak mengalami amputasi sebelumnya.

Tabel 2. Riwayat Penyakit pasien dengan ulkus kaki diabetik di Banjarmasin, Kalimantan Selatan, Indonesia $(\mathrm{N}=134)$

\begin{tabular}{ccc}
\multicolumn{2}{c}{ Indonesia $(\mathrm{N}=134)$} & \\
\hline Variable & N & $\%$ \\
\hline Durasi $\mathbf{D M}$
\end{tabular}

$<5$ tahun

$63 \quad 47$

5 hingga 10 tahun

$32 \quad 23.9$

$>10$ tahun

39

29.1

\section{Penyakit Penyerta}

Tidak

$49 \quad 36.6$

Ya

Ulkus Sebelumnya

Tidak

74

55.2

Ya

60

44.8

Penggunaan Insulin

Tidak

35

26.1

Ya

99

Perawatan Kaki Rutin

Tidak

78

58.2

Ya

56

Pengalaman Amputasi

$\begin{array}{lll}\text { Tidak } & 93 & 69.4 \\ \text { Ya } & 41 & 30.6\end{array}$

Hasil mean dari 8 domain persepsi penyakit dideskripsikan pada tabel 3. Hasil domain persepsi penyakit secara didapatkan consequences (8.24), timeline (7.4), personal control (6.6), treatment control (8), identity (3.5), emotional concern (7.7), emotional response (7.6) dan illnes coherence (5.3). Lebih lanjut, menurut kepercayaan partisipan, 
Dinamika Kesehatan Jurnal Kebidanan dan Keperawatan Vol 10 No. 1 Juli 2019 (ISSN: 2086-3454 EISSN: 2549-4058) url: http://ojs.dinamikakesehatan.unism.ac.id DOI : https://doi.org/10.33859/dksm.v10i1

Persepsi Penyakit Pasien Dengan Ulkus Kaki Diabetik

Di Banjarmasin, Kalimantan Selatan, Indonesia

terdapat 22 penyebab berbeda ulkus kaki

diabetik. Tiga faktor teratas menurut partisipan

adalah tingginya gula darah $(\mathrm{n}=73,18.1 \%)$

keturunan $(\mathrm{n}=58,14.4 . \%)$ dan aktivitas yang

tinggi ( $\mathrm{n}=58,14.4 \%)$. Adapun penyebab ulkus

kaki diabetik berdasarkan persepsi partisipan

dideskripsikan pada tabel 4.

Tabel 3. Persepsi penyakit berdasarkan partisipan

\begin{tabular}{ll}
\hline $\begin{array}{l}\text { Brief Illness Perceptions } \\
\text { Questionnaire Items }\end{array}$ & Mean \pm SD \\
\hline Consequences & $8.2 \pm 1.8$ \\
Timeline & $7.4 \pm 1.6$ \\
Personal control & $6.6 \pm 1.8$ \\
Treatment control & $8 \pm 1.5$ \\
Identity & $3.5 \pm 2.8$ \\
Emotional Concern & $7.7 \pm 2.4$ \\
Emotional response & $7.6 \pm 2$ \\
Illness coherence & $5.3 \pm 2.5$ \\
\hline
\end{tabular}

Tabel 4. Penyebab ulkus kaki diabetik berdasarkan persepsi partisipan

\begin{tabular}{lll}
\hline \multicolumn{1}{c}{$\begin{array}{c}\text { Penyebab Ulkus Kaki } \\
\text { Diabetik }\end{array}$} & Freq. & \% \\
\hline Faktor Internal & 63 & 47 \\
Tingginya gula darah & 34 & 25.3 \\
Aktivitas yang tinggi & 22 & 16.4 \\
Keturunan & 15 & 11.1 \\
Lainnya $^{\mathrm{a}}$ &
\end{tabular}

atermasuk: karma, takdir Tuhan dan ilmu hitam

\section{Pembahasan}

Hasil dari domain consequences $($ mean=8) pada penelitian ini sejalan dengan penelitian lain terkait dampak dari ulkus kaki diabetik. Ulkus kaki diabetik adalah salah satu penyakit yang menyebabkan keterbatasan dalam kegiatan sehari-hari dan menyebabkan dmapak negatif pada aspek fisik, sosial, finansial dan psikologis (Gilpin dna Lagan, 2008).

Hasil mean dari domain timeline (mean=7.4) pada studi ini menunjukan bahwa partisipan percaya ulkus kaki diabetik adalah penyakit kronis yang terjadi dalam jangka waktu yang lama. Hal ini berhubungan dengan motivasi untuk beradaptasi terhadap perubahan perilaku (Al-Smadi dkk, 2016). Namun, hal ini juga dapat menyebabkan rasa beban dan memeprburuk dampak emosional (Järemo dkk, 2017). Hal ini memungkinkan meerupakan jawaban tingginya mean pada domain consequences, emotional response dan emotional concern pada partisipan di penelitian ini.

$$
\text { Mean domain personal control }
$$
(mean=6.6) pada penelitian ini menunjukan adanya keterbatasan pada individu untuk melakukan perilaku kesehatan (Sawicki, 
Sellers dan Robinson, 2011). Untuk mengatasi

hal ini, perawat dapat menguatkan pasien melalui edukasi self-management.

Tingginya skor pada domain treatment control (mean=8) mengindikasikan nilai positif pada perawatan dari dokter dan perawat. Domain ini berkaitan dengan kemauan pasien untuk menjalani pemeriksaan medis rutin (Clarke dkk, 2016), kepatuhan berobat (Hollywood dan Ogden, 2011) dan perawtan luka.

Rendahnya nilai mean pada doman identity $($ mean=3.5) memiliki arti bahwa tanda dan gejala ulkus kaki diabetik sulit diidentifikasi. Gangguan neuropati pada pasien diabetes menyebabkan hilangnya sensasi pada kaki (Otu dkk, 2013), maka individu memiliki kesadaran yang rendah terhadap perlindungan kaki.

Rata-rata nilai pada domain coherence $($ mean=5.3) menunjukan bahwa pasien memiliki keterbatasan dalam pemahaman penyakit ulkus kaki diabetik. Pemahaman terhadap penyakit ulkus kaki diabetik bisa saja tidak tepat dan tidak sejalan dengan ilmu medis, sebagai akibatnya; praktik perawatan diri menjadi tidak sesuai, hasilnya; hanya akan memperburuk, alih-alih menurunkan resiko ulserasi (Walburn dkk, 2017).

Dampak ulkus kaki diabetik memberikan dampak yang besar pada domain respon emosional (mean=7.6) dan kekhawatiran emosional (mean=7.7). Tingginya nilai rata-rata pada kedua domain diartikan sebagai kondisi emosi negatif. Permasalahan kesehatan psikologis memiliki hubungan dengan lemahnya perawatan kaki secara mandiri dan berujung pada terganggunya proses hemostasis, inflamasi, proliferasi dan proses penyembuhan luka secara keseluruhan (Steel, Reece dan Daw, 2016).

Sebagian besar partisipan dalam penelitian ini percaya bahwa tingginya gula darah menyebabkan ulkus kaki diabetik, begitu pula dengan tigginya aktivitas serta faktor keturunan. Akumulasi gula darah dalam jangka waktu yang panjang dapat menyebabkan stress oksidatif, vasokontriksi pada sel syaraf, kontriksi pada pembuluh darah 
Dinamika Kesehatan Jurnal Kebidanan dan Keperawatan Vol 10 No. 1 Juli 2019 (ISSN: 2086-3454 EISSN: 2549-4058) url: http://ojs.dinamikakesehatan.unism.ac.id DOI : https://doi.org/10.33859/dksm.v10i1

Persepsi Penyakit Pasien Dengan Ulkus Kaki Diabetik

Di Banjarmasin, Kalimantan Selatan, Indonesia

dan hiperkoagulability. Kondisi ini neuropati (Witzel dkk, 2015). Kondisi ini menyebabkan kerusakan pada syaraf dan dapat menjadi leih buruk dengan tidak sistem pemnuluh darah pada ekstremitas terkontrolnya gula darah. Maka, pasien bawah, yang mana mengakibatkan diabetes yang memiliki riwayat diabetes dan terganggunya asupan oksigen dan nutrisi, perubahan bentuk kaki dan kehilangan sensasi pada kaki. Dapat ditarik eksimpulan bahwa ulkus kaki diabetik sebaiknya menjadi kelompok target untuk diberikan edukasi terkait resiko terjadinya ulkus kaki diabetik.

hiperglikemi adalah faktor utama yang menyebabkan ulkus kaki diabetik (Clayton dan Elasy, 2009). Tingginya ferekuensi aktivitas dengan beban yang berat menyebabkan penekanan berulang pada area telapak kaki sehingga menyebabkan kerusakan jaringan. Namun, hal tersebut dapat dicegah dengan menggunakan alas kaki yang tepat disertai dengan inspeksi kaki rutin untuk mencegaah terjadinya ulkus kaki diabetik (DiLiberto, Baumhauer dan Nawoczenski, 2016). Maka, diperlukan adanya penguatan untuk menggunakan alas kaki yang tepat selama melakukan aktivitas fisik disertai dengan pemeriksaan fisik secara rutin. Faktor keturunan (elemen genetik yang kita dapat dari orang tua dan keluarga) turut berkontribusi sebagai faktor resiko resistensi insulin dan

\section{Kesimpulan}

Ulkus kaki diabetik memberi banyak dampak negatif pada kehidupan sehari-hari pasien dengan ulkus kaki diabetik. Edukasi dengan pendekatan self-management tentang proses penyakit dapat meningkatkan kemampuan pasien untuk mengidentifikasi tanda dan gejala ulkus kaki diabetik dan dapat meningkatkan kemampuan diri pasien dalam mengontrol penyakitnya. Namun, data yang didapatkan dari BIPQ tidak dapat memberikan penjelasan mendalam terkait masing-masing domain persepsi penyakit. Maka, penelitian lanjutan seperti penelitian explanatory mixed method dapat dilakukan untuk mendapatkan penjelasan dari data kuantitatif secara mendalam. Data lanjutan dari metode 
kualittatif akan sangat berguna untuk

mengkonfirmasi dan menginterpretasi hasil

dari data kuantitatif.

\section{Ucapan terima kasih}

Penelitian ini dibiayai oleh Research and Training Center for Enhancing Quality of Life of Working - Age people Faculty of Nursing, Khon Kaen University, Thailand.

\section{Daftar Pustaka}

Al-Smadi, A. M., Ashour, A., Hweidi, I., Gharaibeh, B., \& Fitzsimons, D. (2016). Illness perception in patients with coronary artery disease: A systematic review. International Journal of Nursing Practice, 22(6), 633-648.

Broadbent, E., Petrie, K. J., Main, J., \& Weinman, J. (2006). The Brief Illness Perception Questionnaire. Journal of Mixed Methods Research, 60(October), 631-637.

Clarke, A. L., Yates, T., Smith, A. C., \& Chilcot, J. (2016). Patient's perceptions of chronic kidney disease and their association with psychosocial and clinical outcomes: a narrative review. Clinical Kidney Journal, 9(3), 494-502.

Clayton, W., \& Elasy, T. A. (2009). A Review of the Pathophysiology, Classification, and Treatment of Foot Ulcers in Diabetic Patients. Clinical Diabetes, 27(2), 52-58.
DiLiberto, F. E., Baumhauer, J. F., \& Nawoczenski, D. A. (2016). The prevention of diabetic foot ulceration: How biomechanical research informs clinical practice. Brazilian Journal of Physical Therapy, 20(5), 375-383.

Gilpin, H., \& Lagan, K. (2008). Quality of life aspects associated with diabetic foot ulcers: A review. The Diabetic Foot Journal, 11(2), 56-62.

Hollywood A and Ogden J (2011). Taking Orlistat: Predicting weight loss over 6 months. Journal of Obesity, $1-7$.

International Diabetes Federation. (2015). International Diabetes Federation: DIABETES ATLAS. (D. Cavan, J. da R. Fernandes, L. Makaroff, K. Ogurtsova, \& S. Webber, Eds.) (7th ed.). International Diabetes Federation.

Järemo, P., Arman, M., Gerdle, B., Larsson, B., \& Gottberg, K. (2017). Illness beliefs among patients with chronic widespread pain - associations with self-reported health status, anxiety and depressive symptoms and impact of pain. BMC Psychology, 5(1), 1-10.

Katavić, S. S., Tanacković, S. F., \& Badurina, B. (2016). Illness perception and information behaviour of patients with rare chronic diseases. Information Research, 21(1) (March).

Mcdonald, S. M. (2011). Perception: A Concept Analysis. International Journal of Nursing Knowledge, 23(1), 2-9.

Lepäntalo, M., Apelqvist, J., Setacci, C., Ricco, J. B., De Donato, G., Becker, F., et al. (2011). Chapter V: Diabetic foot. Eur J Vasc Endovasc Surg, 42(Suppl. 2), S60-S74. 
Leventhal, H., Phillips, L. A., \& Burns, E. (2016). The Common-Sense Model of Self-Regulation (CSM): a dynamic framework for understanding illness self-management. Journal of Behavioral Medicine, 39(6), 935946.

Otu, A. A., Umoh, V. A., Essien, O. E., Enang, O. E., Okpa, H. O., \& Mbu, P. N. (2013). Profile , Bacteriology, and Risk Factors for Foot Ulcers among Diabetics in a Tertiary Hospital in Calabar , Nigeria. Hindawi Publishing Corporation, (December).

Sawicki, G. S., Sellers, D. E., \& Robinson, W. M. (2011). Associations Between Illness Perceptions and HealthRelated Quality of Life in Adults with Cystic Fibrosis. J Psychosom Res, 70(2), 161-167.

Steel, A., Reece, J., \& Daw, A.-M. (2016). Understanding the relationship between depression and diabetic foot ulcers. Journal of Social Health and Diabetes, 4(1), 17.

The Canadian Association of Wound Care. (2016). Wound Care. (S. Rosenthal \& K. Basett, Eds.) (Vol. 14). Douglas Queen.

Vedhara, K., Dawe, K., Wetherell, M. A., Miles, J. N. V, Cullum, N., Dayan, C., et al. (2014). Illness beliefs predict self-care behaviours in patients with diabetic foot ulcers: A prospective study. Diabetes Research and Clinical Practice, 106(1)(July), 67-72.

Vedhara, K., Dawe, K., Miles, J. N., Wetherell, M. A., Dayan, C., Drake, N., et al. (2016). predict mortality. Diabetes Nursing, 20(8), 288-290.

Walburn, J., Weinman, J., Norton, S., Hankins, M., Dawe, K., Banjoko, B., \& Vedhara, K. (2017). Stress, Illness
Perceptions, Behaviors, and Healing in Venous Leg Ulcers: Findings From a Prospective Observational Study. Psychosomatic Medicine, 79(June), 585-592.

Wayne W., D. (1995). Biostatistic: A Foundation of Analysis in the Health Sciences (6th ed.). John Wiley\&Sons, Inc., 177-178.

Witzel, I.-I., Jelinek, H. F., Khalaf, K., Lee, S., Khandoker, A. H., \& Alsafar, H. (2015). Identifying Common Genetic Risk Factors of Diabetic Neuropathies. Frontiers in Endocrinology, 6(May), 1-18.

Yusuf, S., Okuwa, M., Irwan, M., Rassa, S., Laitung, B., Thalib, A., et al. (2016). Prevalence and Risk Factor of Diabetic Foot Ulcers in a Regional Hospital, Eastern Indonesia. Open Journal of Nursing, 6 (January), 1-10. 